PRZEGLĄD BIBLIOTECZNY 2019 z. 1

PL ISSN 0033-202X

KRYSTYNA HUDZIK

Uniwersytet Marii Curie-Skłodowskiej w Lublinie

Biblioteka Główna

e-mail: k.hudzik@umcs.lublin.pl

\title{
ELEKTRONICZNE MATERIAŁY SEMESTRALNE W SIECI W ŚWIETLE PRAWA AUTORSKIEGO W NIEMCZECH
}

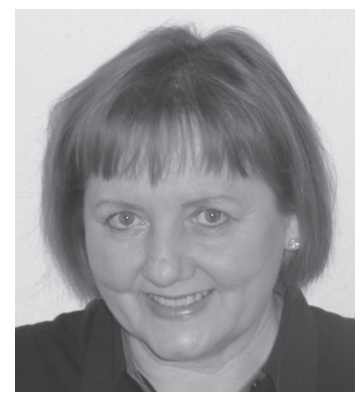

Dr Krystyna Hudzik - pracuje w Bibliotece Głównej UMCS w Lublinie. Autorka książki i kilkunastu artykułów dotyczących niemieckiego bibliotekarstwa. Swoje zainteresowania rozwijała dzięki stażom i praktykom odbytym w bibliotekach uniwersyteckich w Niemczech i w Austrii (Jena, Kolonia, Tybinga, Konstancja, Karlsruhe, Wiedeń) oraz w trakcie rocznego pobytu w Instytucie Nauki o Bibliotece i Informacji Uniwersytetu Humboldtów w Berlinie. Książka Biblioteki uniwersyteckie $w$ Niemczech w epoce cyfrowej: ciagłość i zmiana otrzymała wyróżnienie Rektora Uniwersytetu Warszawskiego dla publikacji akademickiej w dziedzinie nauk społecznych i humanistycznych w konkursie na najlepszą książkę akademicką i naukową ACADEMIA 2018.

SŁOWA KLUCZOWE: Elektroniczne materiały semestralne. Materiały dydaktyczne w sieci. Usługi informacyjne. Biblioteki uniwersyteckie - Niemcy. Prawo autorskie.

ABSTRAKT: Teza/cel artykułu - Prezentacja nowej formy udostępniania materiałów dydaktycznych na uczelnianych platformach e-learningowych, którą w niemieckim bibliotekarstwie określa się jako elektroniczne materiały semestralne (Elektronische Semesterapparate - ESA). Usługa ta zapewnia dostęp do literatury zalecanej przez prowadzących dane wykłady lub seminaria i zawiera informację przeznaczoną dla grupy studentów w nich uczestniczących. Oferuje informację relewantną, wyselekcjonowaną pochodzącą z różnych źródeł cyfrowych i drukowanych oraz przygotowaną do korzystania online. Udostępniane 
materiały zawierają publikacje zarówno dozwolone, jak też chronione prawem autorskim, co jest możliwe dzięki przepisom ograniczającym stosowanie tego prawa w odniesieniu do edukacji i nauki. Zagadnienie ESA omówiono w kontekście zmian prawa autorskiego w Niemczech w ostatnich latach, aż do najnowszej jego nowelizacji, która obowiązuje od 1 marca 2018 r. Przedstawiono najważniejsze przepisy prawa autorskiego dla działalności bibliotecznej. Metoda badawcza - Zastosowano metodę analizy treści - ustalanie najważniejszych źródeł i próba odczytywania znaczeń - tekstów zawartych w specjalistycznym piśmiennictwie, jak również $\mathrm{w}$ informacjach zamieszczonych na stronach internetowych wybranych bibliotek uniwersyteckich. Metodę tę uzupełniono o interpretację odnośnych przepisów prawnych. Pokazano ich realizację na przykładzie wybranych bibliotek. Wyniki/Wnioski - 1) Elektroniczne materiały semestralne (ESA) są nowatorską formą udostępniania literatury potrzebnej w realizacji procesu dydaktycznego. Ich rozwój nastąił pod wpływem technologii cyfrowych i zmian w zakresie komunikacji naukowej; 2) Zmiany w niemieckim prawie autorskim, korzystne dla tworzenia ESA, stanowią efekt zdecydowanego stanowiska zajmowanego przez całe środowisko nauki, a także współpracy w tym zakresie najważniejszych instytucji, organizacji i towarzystw naukowych, m.in. Konferencji Rektorów Szkół Wyższych i Koalicji na Rzecz Prawa Autorskiego dla Edukacji i Nauki.

\section{WSTĘP}

Podstawowym zadaniem biblioteki uniwersyteckiej jest zapewnienie literatury i informacji na potrzeby prowadzonej dydaktyki i badań naukowych. Obydwa obszary są jednakowo ważne dla środowiska akademickiego, lecz od biblioteki wymagają różnych metod rozpoznania potrzeb oraz charakteryzują się różnym stopniem trudności w ich zaspokajaniu. Artykuł poświęcony jest elektronicznym materiałom semestralnym wspomagającym prowadzenie dydaktyki uniwersyteckiej we współczesnych Niemczech. Dotyczy ich prawnych uwarunkowań i regulacji. Nie podejmuje kwestii zadań bibliotek związanych z badaniami naukowymi.

Elektroniczne materiały semestralne są rodzajem usługi w zakresie udostępniania wiedzy i informacji. Ich rozwój należy rozpatrywać w kontekście zmian w komunikacji naukowej pod wpływem nowych technologii informacyjnych, rosnących zasobów cyfrowych, digitalizacji zbiorów drukowanych oraz wpływu środowiska sieciowego na działalność biblioteczną i informacyjną. Transformacja cyfrowa polega na odchodzeniu od fizycznych przedmiotów, takich jak drukowane książki i czasopisma, zmienia je na bity informacji pozbawionej tradycyjnej formy nośnika. Informacja ta może być udostępniana wszędzie: na ekranie laptopa, tabletu lub komórki, w dowolnych miejscach i czasie (Nahotko, 2016, s. 126-127; Wójcik, 2015, s. 567-569).

Elektronicznych materiałów semestralnych (Elektronische Semesterapparate - ESA; ang. Electronic Course Reserve) nie spotyka się w działalności polskich bibliotek. Tym bardziej warto opisać i wyjaśnić znaczenie tego rodzaju usługi, umożliwiającej studentom dostęp online do zalecanej 
literatury z konkretnego przedmiotu. Usługi tej nie należy utożsamiać z dostępem do pojedynczych podręczników i czasopism w wersji elektronicznej na zasadzie ich dowolnego wyszukiwania przez każdego studenta z osobna. Jest ona czymś więcej, stanowi bowiem kompleksową ofertę dostępu do wyselekcjonowanych tekstów odpowiadających tematycznie konkretnym zajęciom - jest informacją dedykowaną precyzyjnie określonej grupie uży tkowników, uczestników danego seminarium czy wykładu. Dzięki temu, logując się na serwerze platformy e-learningowej ILIAS lub Moodle, otrzymują oni w jednym miejscu dostęp do zalecanych tekstów - na przykład do zajęć „Wprowadzenie do socjologii wiedzy” czy „Karykatura w nauczaniu historii" - w postaci, po pierwsze, linków do zasobów licencjonowanych przez uniwersytet, jak i do otwartych zasobów Open Access, po drugie, w formie załączonych plików PDF pochodzących z digitalizowanych specjalnie w tym celu tekstów ze zbiorów drukowanych. Co ważne, wśród digitalizowanych materiałów mogą być artykuły z najnowszych numerów czasopism naukowych oraz fragmenty książek, które podlegają ochronie prawa autorskiego. W Niemczech zezwalają na to odpowiednie przepisy w obowiązującym prawie autorskim, a koszty i rozliczenie z tytułu korzystania z utworów prawnie chronionych pozostają w gestii ministerstw kultury poszczególnych krajów (landów) Federacji.

Kwestia zgodności ESA z obowiązującym prawem była w ostatnich latach przedmiotem intensywnych debat w Niemczech, które zakończyły się nowelizacją tamtejszego prawa autorskiego i wprowadzeniem zapisów korzystnych dla użytkowników i bibliotek. Temu zagadnieniu poświęcone są niniejsze rozważania.

\section{PRAWO AUTORSKIE I JEGO NOWELIZACJA}

Od 1 marca 2018 r. obowiązuje w Niemczech nowe prawo autorskie, opublikowane i ogłoszone w Federalnym Dzienniku Ustaw w dniu 7 września 2017 r., czyli niemal w ostatniej chwili przed wyborami do Bundestagu we wrześniu 2017 r. (Urheberrechtsgesetz, 2017). Zastąpiło ono wcześniejszą ustawę Prawo autorskie i prawa pokrewne z 1965 r., wielokrotnie zmieniana, mająca $w$ swym zapisie dwa istotne paragrafy $-\S 52 a$ dotyczący e-learningu i elektronicznych materiałów semestralnych oraz $\S 52 \mathrm{~b}$ nazwany ,bibliotecznym". Zostały one zapisane w nowej ustawie $\mathrm{w} \S 60 \mathrm{a}$, rozdz. 4, będącym nową regulacją dotyczącą "prawnie dozwolonego korzystania dla celów nauczania (zajęć), nauki oraz instytucji”. Ten od dawna przygotowywany duży projekt legislacyjny stanowi podstawę korzystania z publikacji/dzieł w działalności szkół, uniwersytetów, bibliotek i archiwów, a w założeniu ma także zakończyć trwającą od dawna różnicę zdań między nauka/uczelniami i wydawnictwami/autorami na temat ograniczeń w stosowaniu prawa autorskiego. 
Nowelizacja daje naukowcom, uniwersytetom i bibliotekom pozwolenie, aby naukowe książki i artykuły z czasopism kopiować i korzystać $\mathrm{z}$ nich $\mathrm{w}$ sieci. Celem jest umożliwienie instytucjom naukowym dostępu do tekstów bez konieczności czasochłonnych i uciążliwych negocjacji porozumień z wydawcami i autorami. Dozwolone jest korzystanie z utworów objętych ochroną prawa autorskiego do prowadzenia lekcji w szkole, nauczania w szkołach wyższych, do badań naukowych oraz eksploracji tekstów i danych (Text and Data Mining). Mowa jest o korzystaniu z tych materiałów do celów niekomercyjnych, z dostępem ograniczonym do uczestników nauczania, nauczycieli i egzaminujących (Neues, 2018; Hartmann, 2017). Według ustawy dozwolone są następujące materiały:

- pojedyncze artykuły z czasopism specjalistycznych i inne "małe” dzieła w całości;

- fragmenty z książek - maksymalnie do 15\%; tytuły wyczerpane w całości; ilustracje/rysunki ze specjalistycznych czasopism - w całości.

Ustawa zabrania korzystania z całych artykułów z gazet i czasopism popularnych (Kioskzeitschriften), materiałów z podręczników szkolnych w szkołach oraz danych o źródłach. Stwierdza, że nie ma obowiązku pojedynczego meldowania o korzystaniu z materiałów, a całościowa rekompensata $\mathrm{w}$ formie ramowej umowy ustalana jest $\mathrm{z}$ towarzystwami zarządzania prawami autorskimi (Hartmann, 2017).

Nowa ustawa została pozytywnie przyjęta przez naukowców i biblioteki, ponieważ jasno określa ograniczenia w stosowaniu prawa autorskiego, pozwala na umieszczenie materiałów w sieci uniwersyteckiej na potrzeby e-learningu oraz wskazuje formę i źródło finansowania rekompensaty dla autorów (Hartmann, 2017). Jest ona tym samym realizacją postulatów, które bibliotekarze i naukowcy zgłaszali konsekwentnie od wielu lat. Spróbujmy przedstawić najważniejsze fakty z przeszłości świadczące o solidarnym działaniu całego środowiska nauki na rzecz złagodzenia zbyt restrykcyjnego prawa autorskiego. Historia tych działań legislacyjnych może okazać się pouczająca, chociażby z perspektywy polskich doświadczeń.

Uchylona pierwotna ustawa o prawie autorskim i prawach pokrewnych z 1965 r. była nowelizowana kilka razy, w 2001 r. wprowadzono przepisy dopasowujące ją do dyrektyw Unii Europejskiej oraz traktatu o prawie autorskim Światowej Organizacji Własności Intelektualnej - WIPO Copyright Treaty (WCT), z dnia 20 grudnia 1996 r. (Beger, 2016, s. 930; Hudzik, 2017, s. 101). Wprowadzanie międzynarodowych dyrektyw do prawa narodowego nasuwało jednak więcej problemów niż rozwiązań. Wiele kwestii wymagało orzeczeń najwyższych instancji sądowniczych. W rezultacie niemiecka ustawa zawierała wyjątki i ograniczenia w prawie autorskim z uwagi na interes publiczny i publiczne prawo dostępu do informacji. Potrzebę rozszerzania wyjątków i ograniczeń w prawodawstwie 
narodowym zdecydowanie wyrażały stowarzyszenia bibliotekarskie. Akcentowały one, że nie można zabraniać bibliotekom udostępniania w sieci dzieł przez nie nabytych w celu wspomagania zajęć czy nauczania na odległość. Prawo autorskie nie może redukować działalności bibliotek, utrudniać tworzenia bibliotek cyfrowych przez ograniczenie legalnego korzystania z dzieł objętych ochrona, bo to oznaczałoby stawianie barier aktywności intelektualnej i twórczej. A to jest sprzeczne z dziejową misją bibliotek, w którą wpisane jest zapewnienie dostępu do wiedzy niezbędnej w edukacji, badaniach naukowych oraz dla osiągania tego, co służy dobru publicznemu. Taki sam punkt widzenia prezentowała Koalicja na Rzecz Prawa Autorskiego dla Edukacji i Nauki (Aktionsbündnis „Urheberrecht für Bildung und Wissenschaft", skrót: Urheberrechtsbündnis), którą od czasu jej założenia popierało sześć największych organizacji naukowych w Niemczech, m.in. Konferencja Rektorów Szkół Wyższych, Rada Naukowa, Towarzystwo Maxa Plancka, Towarzystwo Fraunhofera oraz ponad 370 towarzystw naukowych i instytucji. Postulaty Koalicji zostały sformułowane w lipcu 2004 r. w „Deklaracji Getyńskiej w sprawie prawa autorskiego dla edukacji i nauki" - Göttinger Erklärung zum Urheberrecht für Bildung und Wissenschaft (Aktionsbündnis, 2018).

Nagłośnienie sprawy doprowadziło do nowelizacji prawa autorskiego (Urheberrechtsgesetz - UrhG) w styczniu 2008 r., pozwalającej na wykonywanie kopii na użytek publiczny i prywatny (Synopse, 2018). Chodziło o kopie analogowe i cyfrowe dozwolone pod określonymi warunkami i w określonym zakresie, o czym mówiły wymienione już wcześniej dwa paragrafy: § 52a „Udostępnianie na użytek publiczny w sieci na potrzeby edukacji i badań" i $\S 52$ b "Kopiowanie dzieł udostępnionych na stanowiskach komputerowych w publicznych bibliotekach, muzeach i archiwach" oraz kolejny $\S 53$,Zwielokrotnienie na użytek prywatny i inny użytek osobisty". Wymienione przepisy nie były zawsze tak samo interpretowane przez biblioteki oraz właścicieli praw autorskich, dlatego kilka konfliktowych spraw rozstrzygały sądy różnych instancji, a nawet Federalny Trybunał Sprawiedliwości w Karlsruhe (Bundesgerichtshof, BGH). Ten ostatni wydał wyrok w sprawie kopiowania dzieł udostępnianych przez bibliotekę na stanowisku komputerowym, określanym jako elektroniczne miejsce do czytania. Sprawa toczyła się między Biblioteką Uniwersytetu Technicznego w Darmstadt a wydawnictwem Eugen Ulmer Verlag. Wydany wyrok sądowy pozwalał bibliotekom digitalizować książki, które posiadają w swoich zbiorach, po to, by następnie udostępniać je czytelnikom w pomieszczeniach biblioteki na stanowiskach komputerowych, z możliwością ich drukowania i zapisywania na nośnikach pamięci w tym samym zakresie dozwolonego użytku prywatnego, co książki drukowane. Sąd stwierdził dalej, że tego prawa bibliotekom nie uniemożliwiają odpowiednie oferty licencyjne. Biblioteka nie ponosi jednak odpowiedzial- 
ności za bezprawne powielanie dzieła przez użytkownika korzystającego $\mathrm{z}$ niego na stanowisku komputerowym. Wydruk lub zachowanie tekstu na dysku USB może być powielaniem na prywatny i własny użytek osobisty, zgodnie z $§ 53$ ustawy. O całej sprawie poinformował opinię publiczną w dniu 17 kwietnia 2015 r. Niemiecki Związek Bibliotek (Deutscher Bibliotheksverband, dbv) w komunikacie prasowym (Deutscher, 2015).

Pewną osobliwością było zastosowanie § 52a w niemieckim prawie autorskim, pozwalającego na publiczne udostępnianie w sieci dzieł chronionych prawem na potrzeby edukacji i badań. Paragraf ten był w Niemczech wielokrotnie przedłużany od 2003 r. (ostatnie dwuletnie przedłużenie obowiązywało od 10 grudnia 2012 do 31 grudnia 2014), ponieważ o jego utrzymanie upominały się gremia reprezentujące oświatę i szkolnictwo wyższe. Natomiast za zniesieniem paragrafu zdecydowanie opowiadali się wydawcy i księgarze zrzeszeni w Stowarzyszeniu Giełdowym Niemieckich Księgarzy (Börsenverein des Deutschen Buchhandels) oraz Towarzystwo Zarządzania Prawami Autorskimi 'Słowo' (Verwertungsgesellschaft Wort, VG Wort). Rząd federalny konsultował z zainteresowanymi stronami dalsze postępowanie $w$ tej sprawie i opowiadał się bardziej za definitywnym jej rozwiązaniem, niż tylko dalszym przedłużaniem [Deutscher, 2014]. Rządząca koalicja CDU/CSU i SPD przedstawiła projekt nowelizacji ustawy, który stał się podstawą ogłoszenia i wejścia w życie z dniem 5 grudnia 2014 r. ostatecznego utrzymania § 52a na czas nieokreślony [Entfristung, 2014]. Takie rozwiązanie przetrwało do marca 2018 r., gdy weszła w życie nowa ustawa, omówiona na początku tych rozważań.

\section{ELEKTRONICZNE MATERIAŁY SEMESTRALNE (ESA)}

Prezentację nowej usługi informacyjnej w sieci ESA należy rozpocząć od przypomnienia wcześniejszych rozwiązań w udostępnianiu zbiorów dla studentów, które w bibliotekach uniwersyteckich mają długą tradycję, począwszy od tworzenia wydzielonego księgozbioru dydaktycznego, zawierającego podręczniki w wielu egzemplarzach. Kolejną formą są przygotowywane przez bibliotekarzy w ścisłej współpracy z prowadzącymi zajęcia - zarówno dawniej, jak i obecnie - tradycyjne (drukowane) materiały semestralne (Semesterapparate, SA), należące do standardowych praktyk w bibliotekach zarówno w Niemczech, jak również w Austrii i w Szwajcarii ${ }^{1}$.

\footnotetext{
${ }^{1}$ Jako przykład można podać zasady organizacji księgozbioru dydaktycznego i materiałów semestralnych w Centrum Komunikacji, Informacji i Mediów (Kommunikations,- Informations-, Medienzentrum) Uniwersytetu w Konstancji prezentowane w formie dwóch krótkich filmów instruktażowych: Film Lehrbuchsammlung, Film Semesterapparate. [online]. [dostęp 27.05.2018]. Dostępny w WWW: <https://www.kim.uni-konstanz.de/das-kim/informationsblaetter-filme-und-ordnungen/ erklaerfilme>, Przykłady z Austrii i Szwajcarii: Biblioteka Uniwersytetu w Innsbrucku, <https://www. uibk.ac.at/ulb/services/semesterapparate/>, ETH Zürich. Mathematics Library. Course reserve collection (Semesterapparat), <https://www.math.ethz.ch/library/collection/crc.html> [dostęp: 28.12.2018].
} 
Liczą one po kilkadziesiąt tytułów pochodzących nie tylko ze zbiorów biblioteki głównej, lecz także - na zasadzie czasowego wypożyczenia - z innych bibliotek sieci uczelnianej. Na bieżąco są także rozwijane i uzupełniane poprzez kupowanie najnowszych publikacji. Stanowią je specjalnie przygotowane i wydzielone zbiory książek, kopii artykułów z czasopism i innych mediów, przeznaczone dla studentów uczestniczących w zajęciach prowadzonych w danym semestrze przez profesorów i innych samodzielnych pracowników naukowych (często określanych zwyczajowo mianem docentów). Wystawione są w bibliotece głównej lub w bibliotekach dziedzinowych/instytutowych w wolnym dostępie na oddzielnie ustawionych regałach, oznaczone wyraźnie wyeksponowanymi, w kolejności alfabetycznej, nazwiskami wykładowców. Zawierają polecane materiały do wykładów kursowych, ćwiczeń, specjalistycznych seminariów i egzaminów. Zgromadzona $\mathrm{w}$ jednym miejscu literatura dotyczy na przykład takich tematów jak: Metody empiryczne w lingwistyce, Turcja z perspektywy Europy, Skandal i eksperyment w sztuce, czy Materiały do egzaminu z dydaktyki języka francuskiego (Semesterapparate, 2018). Warto w tym miejscu wspomnieć także o materiałach podręcznych (Handapparate) przygotowywanych w pokojach profesorów, które zawierają literaturę z zakresu aktualnie prowadzonych przez nich badań (Handapparate, 2018).

Drukowane materiały semestralne w odróżnieniu od elektronicznych nazywane są konwencjonalnymi lub analogowymi. W praktyce bibliotecznej organizowane są obecnie obydwie formy - zarówno drukowane (SA), jak i elektroniczne (ESA), a informacja o sposobach ich tworzenia oraz udostępniania znajduje się na internetowych stronach bibliotek. Usługi ESA rozwija w Niemczech wiele bibliotek uniwersyteckich, o czym świadczy wynik wyszukiwania w Google terminu "elektronische Semesterapparate”, kierujący do stron WWW ponad 30 różnych bibliotek. Rozwiązania stosowane w kilku z nich zostały wykorzystane poniżej do omówienia zasad tworzenia ESA. Wybrane biblioteki to m.in.: Biblioteka Uniwersytecka i Krajowa Westfalskiego Uniwersytetu Wilhelma w Münster, Biblioteka Uniwersytecka i Krajowa Uniwersytetu Technicznego w Darmstadt, Biblioteka Uniwersytetu Duisburg-Essen, Biblioteka Uniwersytetu Justusa Liebiga w Giessen, Biblioteka Uniwersytecka i Krajowa Uniwersytetu Heinricha Heine w Dusseldorfie, Biblioteka Uniwersytetu w Würzburgu, Biblioteka Uniwersytetu Filipa w Marburgu oraz Biblioteka Uniwersytetu w Trewirze.

Biblioteka Uniwersytecka i Krajowa Westfalskiego Uniwersytetu Wilhelma w Münster zamieściła w zakładce „Usługi” (Service) zasady tworzenia aparatów semestralnych na centralnej platformie e-learningu (Learnweb) oraz linki do formularzy i objaśnień dla docentów w postaci instrukcji liczącej 13 stron. Omówione są w nich także rodzaje materiałów, które można zamieszczać w ESA zgodnie z nową ustawą o prawie autorskim (Elektronischer, 2018). Zamawianie materiałów do ESA odbywa się w elektronicznym 
systemie, który pozwala z opcji wyszukiwania w katalogu bibliotecznym pobierać gotowe pliki z zasobów cyfrowych (artykuły z czasopism, fragmenty książek), a także wysyłać online zamówienia na materiały drukowane w celu ich skanowania w bibliotece. Zamówienia te są odbierane przez zespół bibliotekarzy (ESA-Team), którzy lokalizują dane materiały i sprowadzają je $\mathrm{w}$ razie potrzeby $\mathrm{z}$ bibliotek specjalistycznych, a następnie skanują i automatycznie zamieszczają w formie plików PDF na uniwersyteckiej platformie Learnweb-Kursraum. Materiały z poprzednich semestrów można przenosić na następne, bez potrzeby ich ponownego skanowania. Literaturę, której nie ma aktualnie w zbiorach, biblioteka stara się możliwie szybko uzupełnić.

Przykład z Münster pokazuje wykorzystanie specjalnego modułu programu integrującego system biblioteczny i uniwersytecką platformę e-learningową. Tworzenie ESA odbywa się całkowicie w sieci, zarówno komunikacja osób, jak też pobieranie, wysyłanie i wgrywanie danych. Dzięki temu modułowi nastąpiła całkowita automatyzacja procesu przygotowywania ESA, przez co powstała tym samym także nowa płaszczyzna współpracy między pracownikami naukowymi i bibliotekarzami, dająca w efekcie wirtualne zarządzanie rozproszonymi/zdecentralizowanymi dokumentami. $\mathrm{W}$ rezultacie studenci mogą korzystać z nich w jednym punkcie dostępu. Zaletą modułu jest także zachowanie transparentności w przebiegu całego procesu, jak również możliwość sprawdzania przez wykładowców statusu realizacji zamówień na digitalizację materiałów drukowanych.

Z kolei Biblioteka Uniwersytecka i Krajowa w Düsseldorfie przedstawia na stronie internetowej informację o 363 aktywnych materiałach semestralnych w formie wykazu ułożonego w kolejności alfabetycznej nazwisk samodzielnych pracowników naukowych (docentów). Dodatkowym ułatwieniem jest wyszukiwarka pozwalająca odnajdować materiały drukowane według miejsca ich lokalizacji w bibliotekach specjalistycznych, a w przypadku ESA według numeru dokumentu na serwerze, który stanowi jednocześnie aktywny link dostępu. Rysunek 1 przedstawia elementy rekordu opisującego dane ESA dla przykładowych zajęć na temat „Federalizmu”, które prowadzi Stefan Bajor.

Warto zwrócić uwagę na dwa linki znajdujące się po prawej stronie opisywanego rekordu, jeden $\mathrm{z}$ adresem e-mail profesora prowadzącego zajęcia, drugi - służący do pobrania statystyki wykorzystania materiałów. W analizowanym przypadku materiałów do zajęć na temat „Federalizmu” otrzymujemy następujące dane statystyczne za trzy ostatnie miesiące roku 2018: w październiku - dostępów ogółem było 369, w tym 33 do opisu dokumentu i 336 do poszczególnych danych oraz analogicznie w listopadzie - 346, w tym 7 i 339 i grudniu - 162, w tym 1 i 161. Wprawdzie nie znamy liczebności grupy uczestniczącej w tych zajęciach, jednak wymienione liczby (łącznie 877 sesji) niewątpliwie wskazują na to, że ESA cieszą się zainteresowaniem wśród studentów i są często wykorzystywane. 


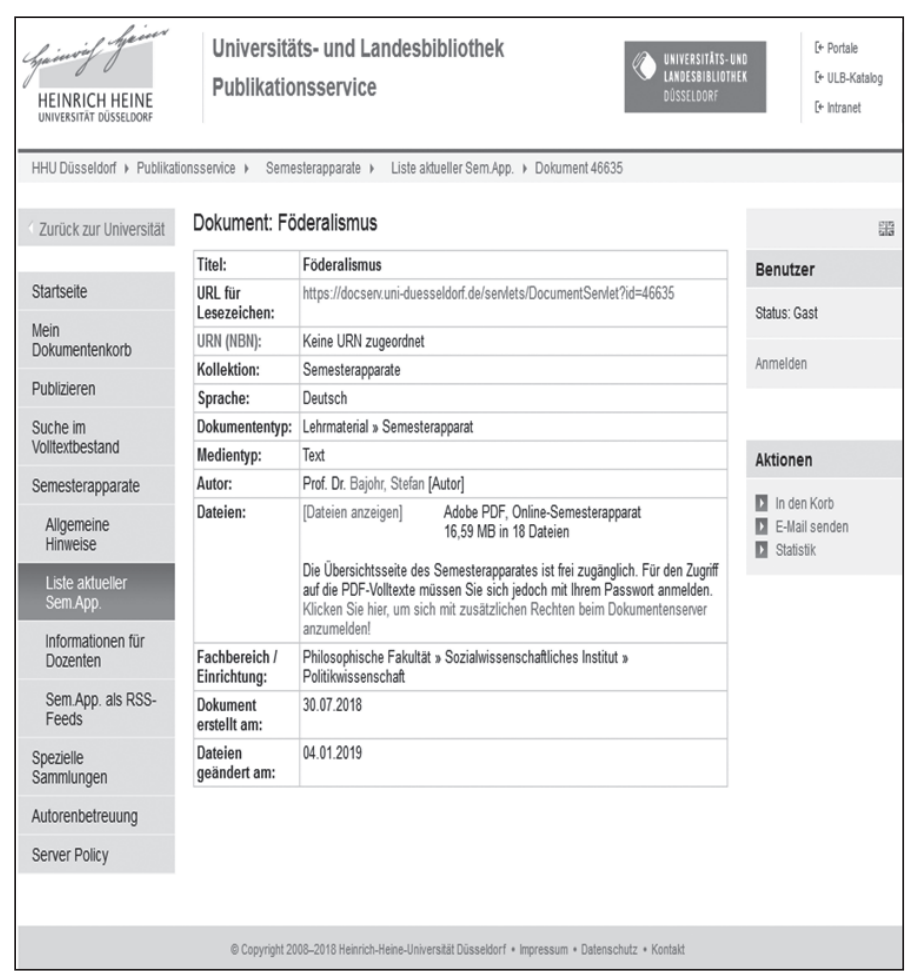

Rys. 1. Dokument: Föderalismus

Źródło: [online]. Dostępny w WWW: <https://docserv.uni-duesseldorf.de/servlets/DocumentServlet?id=46635> [dostęp: 05.01.2019].

Elektroniczne materiały semestralne należy więc postrzegać jako kolejny etap w działalności bibliotek, którym udało się dzięki zastosowaniu nowych narzędzi i sposobów udostępniania informacji, rozwinąć usługę mającą cechy najbardziej oczekiwane przez użytkowników. Oznacza to, że jest ona świadczona online w systemie 24/7, dostarcza informację relewantną i spersonalizowana, zapewnia pośredni sposób komunikacji, eliminuje bariery w dostępie do informacji, gwarantuje szybkość w dotarciu do potrzebnych dokumentów i minimalizuje czas oczekiwania na nie (Wójcik, 2015).

Jeśli chodzi o problem ograniczeń i barier w dostępie do wiedzy i informacji, ESA pozwalaja jak widać, na pokonanie barier środowiskowych, m.in. prawnych, związanych w szczególności z prawem autorskim, niekorzystnym dla czytelników. Eliminują one również bariery związane z dotarciem do źródeł informacji - ich brak w bibliotece oraz nieprzyjazne regulaminy: ograniczenia w sporządzaniu kopii, udostępnianie materiałów tylko na miejscu, limity na koncie czytelnika czy niedogodne godziny otwarcia biblioteki. Istnieją też jeszcze inne typy barier, które skutecznie pokonują ESA 
- przede wszystkim bariera nadmiaru informacji w sytuacji, gdy ogromna liczba tytułów czasopism, książek i linków do stron internetowych nie przekłada się na przyrost wiedzy, a tylko absorbuje czas na ich wyszukiwanie, kopiowanie i skanowanie. Ważne jest również wyeliminowanie w przypadku ESA bariery nierelewantności, czyli sytuacji, gdy wiedza i informacja, do których dotarł użytkownik, nie zaspokajają jego potrzeb w tej materii (Świgoń, 2014, s.10-12).

Elektroniczne materiały semestralne dostępne są tylko dla uprawnionej grupy studentów danego seminarium czy wykładu i korzystanie z nich wymaga indywidualnego logowania i podania hasła. Zamieszczone pliki cyfrowe po zakończonym semestrze należy usunąć z serwera. Za publiczne korzystanie w sieci z utworów chronionych prawem autorskim, ich twórcy otrzymują wynagrodzenie obliczane ryczałtem lub w kwocie ustalonej $\mathrm{w}$ umowie zbiorowej $\mathrm{z}$ towarzystwami zarządzania prawami autorskimi Verwertungsgesellschafte, VG (Beger, 2016, s. 936). W przypadku autorów tekstów jest to wspomniane wcześniej VG Wort, muzyków - Towarzystwo GEMA, a twórców sztuk plastycznych i filmów - VG Bild-Kunst. Drugą stronę, czyli szkoły, uniwersytety i biblioteki, reprezentuje w negocjacjach i zawieranych umowach Konferencja Ministrów Kultury (KMK), regulująca jednocześnie należne koszty ${ }^{2}$.

Biblioteki uczestniczą w przygotowaniu cyfrowych zasobów dydaktycznych, zwłaszcza - zgodnie z tradycją - w odniesieniu do zajęć prowadzonych przez profesorów. Pomocni w tym są także sami studenci (Studentische Hilfskraft), zatrudniani na uniwersytetach niemieckich dość często $\mathrm{w}$ katedrach i instytutach $\mathrm{w}$ określonym wymiarze godzin (Nebenjob). Natomiast młodsi pracownicy naukowi wykonują wiele z wymaganych na rzecz ESA czynności, przeważnie sami (ESA, 2018; Elektronische Semesterapparate, 2018).

Zadania bibliotekarzy, poza digitalizowaniem na zamówienie zbiorów drukowanych, polegają na sprawdzaniu zgodności udostępnianych w ESA materiałów z obowiązującymi przepisami i udzielaniu porad pracownikom naukowym w zakresie prawa autorskiego. W tym celu wykorzystują również strony internetowe bibliotek, gdzie zamieszczają objaśnienia w formie „najczęściej zadawanych pytań i odpowiedzi” (FAQ), interpretacji przepisów prawa autorskiego w oparciu o konkretne przykłady materiałów bibliotecznych oraz $\mathrm{w}$ postaci wizualnych prezentacji. Jako przykłady takich rozwiązań można podać Bibliotekę Uniwersytetu w Duisburgu-Essen (FAQ, 2018) oraz Centrum Komunikacji, Informacji i Mediów Uniwersytetu

${ }^{2}$ Wynagrodzenie stanowi przedmiot negocjacji między stronami i jego wysokość nie była znana w dniu obowiązywania nowego prawa autorskiego. Informacja o tym jest zamieszczona na stronie Biblioteki Uniwersytetu Duisburg-Essen „Vergütung ab dem 01.03.2018. Noch sind die KMK und VG WORT Vertragsverhandlungen über eine Vergütungsvereinbarung für die gesetzlich erlaubten Nutzungen für Unterricht, Wissenschaft und Institutionen nach § 60 a, c, h UrhG (neu) nicht abgeschlossen". [online]. [Dostęp: 10.06.2018]. Dostępny w WWW: https://www.uni-due.de/ub/urheberrecht/. 
w Konstancji (Änderungen, 2018). Z kolei kolorowa ilustracja na stronie Biblioteki Uniwersyteckiej i Krajowej Uniwersytetu Technicznego w Darmstadt prezentuje $\mathrm{w}$ trzech grupach materiały, które można udostępniać elektronicznie na potrzeby dydaktyki w szkołach wyższych, (Welche, 2018):

1. Materiały dozwolone według $\S 60$ a prawa autorskiego: do $15 \%$ dzieła opublikowanego (także publikacji zagranicznych); dzieła w całości, jeśli nakład jest wyczerpany; artykuły z naukowych czasopism specjalistycznych w całości; ilustracje w całości (także fotografie); dzieła niewielkiej objętości w 100\% (tekst do 25 stron, wydawnictwa nutowe do 6 stron, filmy do 5 minut; dzieła muzyczne do 5 minut), a w przypadku dużej objętości wymienionych dzieł, obowiązuje zasada do $15 \%$ dzieła.

2. Materiały Open Access oraz treści własnego autorstwa: małe fragmenty $\mathrm{w}$ ramach prawa do cytowania; własne skrypty, podręczniki i materiały; materiały publikowane na zasadach wolnych licencji (Creative Commons), zgodnie z warunkami licencji; dzieła po okresie 70 lat od śmierci autora; dzieła z domeny publicznej; publikacje Open Access.

3. Materiały dostępne za zasadzie nabytych licencji: licencji narodowych, licencji zakupionych na dostęp w sieci uniwersyteckiej, licencji indywidualnych (umowy z właścicielami praw autorskich).

I jeszcze uzupełnienie: materiały, których nie wolno zamieszczać w sieci w celach dydaktycznych stanowią: więcej niż 15\% dzieła opublikowanego; artykuły z prasy codziennej i kolorowych gazet w całości; wydawnictwa nutowe, filmy, dzieła muzyczne powyżej 15\% dzieła; filmy kinowe przed upływem 2 lat od premiery.

Przyjęte w Niemczech przepisy prawne sprzyjają rozwijaniu usług elektronicznego udostępniania materiałów dydaktycznych, co zachęca zarówno pracowników naukowych, jak i biblioteki do współpracy w tym zakresie. O tym, że elektroniczne materiały semestralne stanowią bogatą ofertę, świadczą ich wykazy liczące po kilkaset pozycji, m.in. w Bibliotekach Uniwersyteckich w Duisburgu-Essen i Jenie ${ }^{3}$.

\section{UWAGI KOŃCOWE}

Biblioteki uniwersyteckie dokonują ciągłych zmian w celu poszerzania oferty usług w sieci, poza własną fizyczną przestrzenią oraz starają się je dostosować do oczekiwań swoich użytkowników. Udostępnianie materiałów dydaktycznych w Internecie, ściśle dostosowanych do potrzeb studentów w danym semestrze i w odniesieniu do konkretnych tematów

\footnotetext{
${ }^{3}$ Wykaz na stronie internetowej Biblioteki Uniwersytetu Duisburg-Essen zawiera ponad sto drukowanych i prawie tysiąc elektronicznych materiałów semestralnych. Lista Biblioteki Uniwersyteckiej i Krajowej Turyngii w Jenie wymienia prawie 300 pozycji. [dostęp: 01.07.2018]. Dostępny w WWW: $<$ https://semapp.uni-due.de/>; <https://www.thulb.uni-jena.de/Kontakt+_+Service/E_Semesterapparate.html>.
} 
zajęć, kursów, seminariów i wykładów, stanowi rozwiązanie optymalne i innowacyjne. Tworzeniu elektronicznych aparatów semestralnych sprzyja w Niemczech ostatnia nowelizacja prawa autorskiego w 2018 r., na co znaczący wpływ miało solidarne stanowisko najważniejszych instytucji, organizacji i towarzystw naukowych na czele z Konferencją Rektorów Szkół Wyższych, które założyły Koalicję na Rzecz Prawa Autorskiego dla Edukacji i Nauki. Nie ma tu zatem mowy o przypadku. Poczynania te świadczą o spójnej polityce naukowej, w której ważne miejsce zajmują także biblioteki uniwersyteckie. W omawianym przypadku upominanie się przez biblioteki o dogodne dla ich działalności regulacje w prawie autorskim, znalazło wsparcie ze strony prestiżowych instytucji naukowych. Wsparcie dotyczy również kwestii finansowych, czyli opłat za korzystanie z dzieł podlegających ochronie prawa autorskiego, które przejęły na siebie rządy poszczególnych landów, a koordynacją całego przedsięwzięcia zajmuje się Konferencja Ministrów Kultury (Kultusministerkonferenz, KMK). Jest ona stałą formą urzędowania ministrów kultury poszczególnych krajów Federacji, decydującą o finansowaniu również innych inicjatyw bibliotecznych, takich jak m.in. "Sieć kompetencji dla bibliotek” (internetowa platforma służąca współpracy, normalizacji i modernizacji bibliotek) oraz Niemiecka Biblioteka Cyfrowa ${ }^{4}$.

\section{BIBLIOGRAFIA}

Aktionsbündnis (2018) „Urheberrecht für Bildung und Wissenschaft“ [online], [dostęp: 2.06.2018]. Dostępny w WWW: <http://www.urheberrechtsbuendnis.de/unterzeichner. html.de>.

Änderungen (2018). Änderungen im Urheberrecht ab dem 01.03.2018. [online]. Kommunikations,- Informations-, Medienzentrum Universität Konstanz. [dostęp: 30.06.2018]. Dostępny w WWW: <https://www.kim.unikonstanz.de/typo3temp/secure_downloads/72591/0/38d5b99bfc638abff029866087a356740bc736a9/Urheberrecht2018.pdf>.

Beger, Gabriele (2016). Urheberrecht. W: Praxishandbuch Bibliotheksmanagement. Bd. 2. (Hrsg.) Rolf Griebel, Hildegard Schäffler, Konstanze Söllner. Berlin, Boston: De Gruyter, S. 930-946.

Deutscher (2014). [online]. Deutscher Bibliotheksverband unterstützt die Entfristung des § 52a UrhG : Pressemitteilung des dbv. [dostęp: 2.06.2018]. Dostępny w WWW: <https:// www.bibliotheksverband.de/dbv/presse/presse-details/archive/2014/november/article/deutscher-bibliotheksverband-unterstuetzt-die-entfristung-des-52a-urhg.html?tx ttnews[day] $=28 \&$ cHash $=53575322 \mathrm{c} 7>$.

Deutscher (2015). [online]. Deutscher Bibliotheksverband begrüßt BGH Entscheidung zu elektronischen Leseplätzen. [dostęp: 21.06.2018]. Dostępny w WWW: <http://www. bibliotheksverband.de/dbv/presse/presse-details/archive/2015/april/article/deutscherbibliotheksverband-begruesst-bgh-entscheidung-z>.

${ }^{4}$ Kultusministerkonferenz [dostęp: 05.01.2019] <https://www.kmk.org/themen/hochschulen/bibliotheken.html>. 
Elektronische Semesterapparate (2018). Elektronische Semesterapparate. [online]. Universitätsbibliothek Philips Universität Marburg. [dostęp: 1.07.2018]. Dostępny w WWW: <https:// www.uni-marburg.de/de/ub/lernen/semesterapparate/elektronische-semsterapparate>.

Elektronischer (2018). Eletronischer Semesterapparat - ESA. [online]. Universitäts- und Landesbibliothek Münster. [dostęp: 30.06.2018]. Dostępny w WWW: <https://www. ulb.uni-muenster.de/service/esa/dozenten-info.html>.

Entfristung (2014) [online]. Entfristung des § 52a UrhG. Am 5.12.2014 wurde der als „Intranetklausel" oder auch „Wissenschaftsschranke” bezeichnete § 52a UrhG endgültig entfristet [dostęp: 2.06.2018]. Dostęp ny w WWW: <http://www.cr-online.de/29384.html>.

ESA (2018). ESA - Elektronische Semesterapparate. [online]. Universitätsbibliothek. Universität Würzburg. [dostęp: 30.06.2018]. Dostępny w WWW: <https://www.youtube. com/watch?v=Yt-3poVKupo>.

FAQ (2018). Semesterapparate: FAQ. [online]. Universität Duisburg-Essen. [dostęp: 30.06.2018]. Dostępny w WWW: <https://semapp.uni-due.de/faq>.

Handapparate (2018). [online]. Universitätsbibliothek Erfurt. [dostęp: 27.05.2018]. Dostępny w WWW: <https://www.uni-erfurt.de/bibliothek/ub/ausleihe/handapparate/>.

Hartmann, Thomas (2017). Heureka - das Urheberrecht ist reformiert! Zu den ab 2018 gesetzlich erlaubten Nutzungen für Unterricht, Wissenschaft und Institutionen. [online]. (Wersja audio wykładu oraz folie z tekstem. Wykład wygłoszony w dniu 05.12.2017 r. w Instytucie Nauki o Bibliotece i Informacji w Uniwersytecie Humboldtów w Berlinie w ramach cyklu Berliner Bibliothekswissenschaftliches Kolloquium). [dostęp: 2.06.2018]. Dostępny w WWW: <https://www.ibi.hu-berlin.de/de/bbk/abstracts/ws1718/Hartmann>.

Hudzik, Krystyna (2017). Biblioteki uniwersyteckie w Niemczech w epoce cyfrowej: ciagłość i zmiana. Warszawa: Wydaw. SBP, s. 100-107.

Neues (2018). Neues Urheberrechtsgesetz für die Wissenschaft. [online]. Bundesministerium für Bildung und Forschung. [dostęp: 28.12.2018]. Dostępny w WWW: <https:// www.bmbf.de/de/neues-urheber rechtsgesetz-fuer-die-wissenschaft-4431.html>.

Nahotko, Marek (2016). Działalność informacyjna. W: Nauka o informacji. Pod red. Wiesława Babika. Warszawa: Wydaw. SBP, s. 123-156.

Semesterapparate (2018). Semesterapparate. Aktuelle Liste. [online]. Universität Duisburg-Essen [dostęp: 26.06.2018]. Dostępny w WWW: <https://semapp.uni-due.de/>.

Synopse (2018). Synopse Urheberrechtsgesetz. Änderungen zum 1.1.2008. [online]. Änderung zum 1.1.08.: § 52b, § 53, §53a. [Dostęp: 28.12.2018]. Dostępny w WWW: <https:// dejure.org/aenderungen/synopse-UrhG-2008.html>.

Świgoń, Marzena (2014). Bariery i ograniczenia w dostępie do wiedzy i informacji - terminologia i klasyfikacja. Nowa Biblioteka, nr 1 (14), s. 7-14.

Urheberrechtsgesetz (2017). Urheberrechtsgesetz (Gesetz über Urheberrecht und verwandte Schutzrechte) vom 01.09.2017 (BGBl. I S. 3346), [online]. Dostęp:1.06.2018]. Dostępny w WWW: <https://dejure.org/gesetze/UrhG>.

Welche (2018). Welche Materialien dürfen in der Hochschullehre elektronisch zur Verfügung gestellt werden? [online]. Technische Universität Darmstadt [dostęp: 30.06.2018]. Dostępny w WWW: <https://www.e-learning.tu-darmstadt.de/dienstleistungen/rechtsfragen/index.de.jsp $>$.

Wójcik, Magdalena (2015). Typologia współczesnych usług informacyjnych. Przegląd Biblioteczny, R. 83, z. 3, s. 563-578. 


\author{
KRYSTYNA HUDZIK \\ Maria Cure-Skłodowska University in Lublin \\ Main Library \\ e-mail: k.hudzik@umcs.lublin.pl
}

\title{
DIGITAL SEMESTRAL RESOURCES AVAILABLE ONLINE AND GERMAN COPYRIGHT
}

KEYWORDS: Digital semestral resources. Teaching resources available online. Information services. German University libraries. Copyright.

ABSTRACT: Thesis/Objective - The article provides a discussion of a new distribution method for teaching resources via the University e-learning platforms, known to German librarians as electronic semestral resources (Elektronische Semesterapparate - ESA). This method offers access to literature recommended by the university lecturers and contains information addressed to the students participating in given courses. The information included in the resources is relevant, selected, derived from the multitude of digital and printed sources and adjusted to be used online. Resources made available in that form contain both free and copyrighted publications - it is possible with the regulations waiving the copyright for the education and science purposes. ESA is discussed in the context of copyright changes in Germany in the recent years up to its most recent update valid since March 1, 2018. The author also presents the most important copyright regulations concerning the library activity. Research method - The analysis of the content is applied, that is, the most important sources are researched and an attempt is made at the identification of the meaning. The content analyzed are texts included in the professional literature and the websites of selected university libraries. This method is complemented with the interpretation of the respective regulations. Further, their implementation in the selected libraries is discussed. Results/Conclusions - 1) Electronic semestral resources (ESA) are a novelty method of distributing literature required for the fulfillment of the teaching process. Their development was possible with the digital technologies and changes in scholarly communication. 2) The transformation of German copyright, beneficial for ESA development, are a result of a firm stance of the whole scholarly community as well as the collaboration the most significant institutions, organizations and scholarly associations, for instance the Bpard of the University Presidents and the Coalition for the Copyright for the Education and Science Purposes. 